\title{
MORPHOLOGY OF THE REPRODUCTIVE TRACT AND SERUM PROGESTERONE CONCENTRATIONS IN COWS WITHIN 45 DAYS AFTER PARTURITION
}

\author{
R. DOLEŽEL, E. KUDLÁC and Jarmila NEDBÁLKOVÁ \\ Department of Farm Animal Reproduction, University of Veterinary Science, \\ 61242 Brno
}

Received April 5, 1990

\begin{abstract}
Doležel R., E. Kudláč, Jarmila Nedbálková: Morphology of the Reproductióe Tract and Serum Progesterone Concentrations in Cows Within 45 Days after Parturition. Acta vet. Brno, 60, 1991: 181-192.

To ascertain serum progesterone concentrations in cows (Bohemian Pied $\times$ Holstein-Friesian) under standard husbandry practices clinical observations were made and blood samples from v. jugularis were taken in five-day intervals within 45 days after parturition, and a post-mortem macroscopic examination of reproductive organs of a selected group of cows were carried out within 35 days post partum. We clinically demonstrated the closing of the orificii cervicis internum and externum by day $15-20$ and day 30 post partum, respectively. The uterus continuously retracted into the pelvis within 20 days post partum and its wall regained characteristics of a nongravid uterus by day 10 . Ovaries were palpable from day 5-10 post partum and from day 35 usually exhibited a typical finding of a sexual cycle. Macroscopic examination showed that the uterus was reducing its size markedly until day 10 , and less markedly until day $20-25$ post partum. Its mass decreased from $10 \pm 1.6$ on the day of parturition to $2.3 \pm 0.9 \mathrm{~kg}$ on day 10 and to $0.9 \pm 0.0$ on day 20 post partum. The average mass of ovaries contralateral to the previously pregnant uterine horn gradually grew from $3.7 \pm 0.91 \mathrm{~g}$ on day 10 post partum to $6.8 \pm 3.06 \mathrm{~g}$ on day 20 , when it was heavier than ipsilateral ovaries $(6.3 \pm 2.92 \mathrm{~g})$. The number of ovarian follicles 1 to $3 \mathrm{~mm}$ in size grew markedly between day 5 and 15 post partum. From day 5 post partum, ovaries exhibited increased numbers of follicles exceeding $3 \mathrm{~mm}$ in size. Slightly increased serum progesterone concentrations $(0.6-1.0 \mathrm{ng} / \mathrm{ml})$ were found most frequently on days 20 and 25 post partum. Later, the number of cows with a concentration of 1.1 or more increased gradually.
\end{abstract}

Post-partum period, uterus, ovaries, follicles, serum progesterone, cow

An early completion of post-partum structural and functional changes of reproductive organs in cows together with the onset of a cyclic ovarian activity is of paramount importance for achieving a continuous intensive reproduction in cattle. The opinions on when uterine involution in cows is completed are far from unanimous, the periods mentioned ranging between 16 and 60 days post partum (Rasbech 1950; Sipilov 1958, Schultz and Grunert 1959; Gier and Marion 1968; Morrow et al. 1969; Studer and Morrow 1981; Hafez 1987; Kudlác and Elečko 1987; Arthur et al. 1989) Besides a large number of endogenous and exogenous factors influencing the involution, the differences also result from the fact that different criteria and more or less accurate indices are used. For similar reasons, the data on the onset of the cyclic ovarian activity exhibit considerable variations. Simultaneous growth, atresia and luteinization of follicles in the post-partum period leads, by a mechanism which has not yet been quite elucidated, to the selection of a dominant preovulatory follicle, ovulation and the appearance of the first cyclic corpus 
luteum. The first maturation wave of ovarian follicles around day 15 post partum does not frequently culminate in ovulation: the follicles are subject to atresia or luteinization with subsequent regression. For this reason, some cows may exhibit symptoms of oestrus, but without subsequent ovulation. Much more frequently, however, first post-partum ovulations are not accompanied by the characteristic external symptoms of oestrus. Continuous monitoring using a video camera showed that only $50 \%$ of cows exhibited symptoms of oestrus at the first ovulation, while at the second and the third ovulation it was $94 \%$ and $100 \%$ of cows, respectively. The number of cows in oestrus detected by the farmer in the 1st, 2nd and 3rd oestrus was $16 \%, 43 \%$ and $53 \%$ respectively ( $\mathrm{K}$ ing et al. 1976). The data on the first post-partum ovulation range between 14 and 65 days post partum and the first post-partum oestrus occurs on days 25 to 85 post partum (Kudláč 1964; Marion and Gier 1968; Marrow et al. 1969; Wagner and Hansel 1969; Kudláč and Vlček 1970; Moller 1970; Thatcher and Wilcox 1973; Britt et al. 1974; Whitemore et al. 1974; Kesler et al. 1979; Studer and Morrow 1981; Garcia and Larsson 1982; Studencov et al. 1986; Hafez 1987; Kudláč and Elečko 1987; Arthur 1989).

Although the basic data on clinical and macroscopic changes on the genital tract of cows in the post-partum period are well-known, the information on a detailed study of the dynamics of these changes in literature is insufficient. And because these issues constitute a considerable part of the veterinarian's work, we believe that it is essential that our knowledge on the course of these changes be extended and presented for general discussion in the literature. It is the only way how the results of clinical examinations loaded with subjective errors on the part of the researchers can be made more objective, and relatively accurate parameters for these investigations can be set up. Our paper presents a detailed analysis of clinical and macroscopic changes on the reproductive tract of cows within $\mathbf{4 5}$ days post partum and results of a monitoring of serum progesterone concentrations.

\section{Materials and Methods}

In the course of investigations carried out in a large-scale cattle production unit, clinical examinations were made and blood samples from $v$. jugularis were taken to ascertain serum progesterone concentrations in five-day intervals from parturition to day 45 post partum in a group of 200 randomly selected pluriparous cows, crossbreds of Bohemian Pied and Holstein-Friesian cattle, divided into groups of 20. The cows were housed in standard 2-4 row barns with stanchions, their feed consisted mainly of green lucerne and maize silage, lucerne hay and fermented straw in winter. Calves were placed in boxes and were released for suckling in the first two to three weeks after birth. In the period of investigations, the average yield of the herd was about 44501 per dairy cow.

The experimental part of our work was carried out at the Department of Farm Animal Reproduction of the University of Veterinary Science in Brno. The experimental group consisted of 24 pluriparous cows of the same breed, housed together with their calves and fed hay and concentrate. Following a clinical examination and blood sampling, groups of three cows each were slaughtered at five day intervals from parturition to day 35 post partum. Macroscopic examination of their reproductive tract was performed immediately.

No animal included in the experiment exihibited any clinical symptoms of impaired health after physiological parturition. Adspection of the vaginal wall and vaginal secretion was made per vaginam, and adspection and palpation was used to ascertain the positioning of the portio vaginalis uteri and the degree of the extension of the cervix uteri. Rectal palpation was used to ascertain the positioning of the uterus, the width of its individual parts (in about a third of the section examined), the properties of its wall, its content if any, and the positioning, size and surface changes of ovaires. Owing to the fact that all of these examinations were made by one person only, their results are loaded with the same subjective error. The approximate dimensions ascertained by palpation were expressed in metric units and to take the measurements, the worker used the palm of his hand $(10 \mathrm{~cm}$ wide) and fingers $(2 \mathrm{~cm}$ wide). In ascertaining the dimensions of ovaries by palpation, we used the frequent comparison to a small, medium or large plum $(3 \times 2 \times 2 \mathrm{~cm}, 3.5 \times 2.5 \times 2 \mathrm{~cm}$ and $4 \times 3 \times 2.5 \mathrm{~cm}$ respectively). In macroscopic examination of the genital tract of slaughtered cows in the post-partum period, we focused on the width of individual sections of the uterus lying on a plate (in a third of its length), the length and dimensions of ovaries, we assessed ovarial structures and weighed the uterus and the ovaries. Serum progesterone concentrations were determined by means of a RIA method after Píchová (1977). As a part of the macroscopic examination, a statistical evaluation of uterine dimensions was performed by means of the Student's t-test between a group of cows on the day of parturition and at a given interval after parturition. 


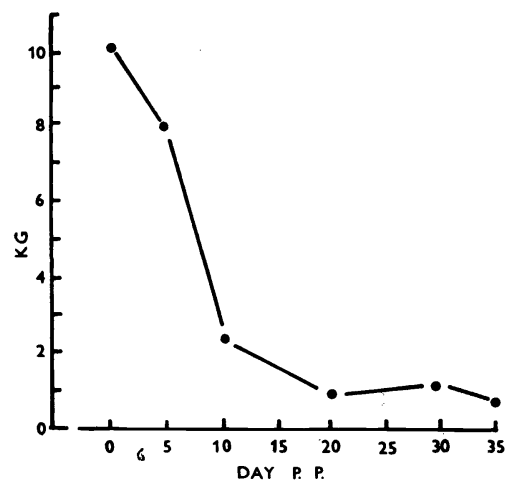

Fig. 1. Average mass of the bovine uterus related to post partum interval

\section{Results}

a) Clinical Examinations (Per Vaginam)

On the parturition day, the portio vaginalis uteri was clearly displaced ventrally or ventrolaterally in the direction of the previously pregnant uterine horn. The ventral displacement was reduced on day 5 and on day 10 appeared only rarely. From day 15 on, it was positioned centrally.

After parturition, the orificium cervicis externum was gradually closing until day $25-30$ post partum. It was $8-12 \mathrm{~cm}$ wide on the parturition day, $4-6 \mathrm{~cm}$ on day $5,2-5 \mathrm{~cm}$ on day 10 and $1-4 \mathrm{~cm}$ on day 15 and 20 . On days 25 and 30, the orificium cervicis externum was only slightly open $(1$ to $3 \mathrm{~cm})$, mostly impassable for a finger, or completely closed.

The size of the orificium cervicis internum gradually narrowed from $6-8 \mathrm{~cm}$ on the parturition day to $2-4 \mathrm{~cm}$ on day 5 and $1-3 \mathrm{~cm}$ on day 10 , when it was often impassable for a finger. On day 15 it was still open $(1-3 \mathrm{~cm})$ in a few cases only and from day 20 it was completely closed in all animals.

Hyperaemia of the vaginal wall with small lacerations in the vicinity of the portio vaginalis uteri was gradually decreasing from the parturition day to day 25 post partum. On the parturition day, vaginal discharge was blood-tinged but in the course of the next 15 days, the blood content gradually decreased and the secretion began to resemble while mucus.

b) Clinical Examination (Per Rectum)

On the parturition day, we found the cervix uteri in the abdominal cavity before the cranial end of the pelvic floor, the corpus and horns reached cranioventrally deep into the abdominal cavity, and palpation per rectum failed to determine their extent. On day 5, the cervix uteri was above the cranial end of the pelvic floor, the corpus was palpated in the abdominal cavity and the uterine horns, placed far in the cranioventral direction, were usually unidentifiable from the cranial side. The previously nonpregnant horn was identifiable in some cases, while both uterine horns only exceptionally. On day 10, the cervix uteri and corpus were placed in a similar position, uterine horns were closer to the pelvic cavity, partially twisted in a ventrolaterocaudal direction or extended cranioventrally deeper in the abdominal cavity. The previously pregnant horn was frequently unidentifiable from the cranial side, the other horn was shorter and usually identifiable. On day 


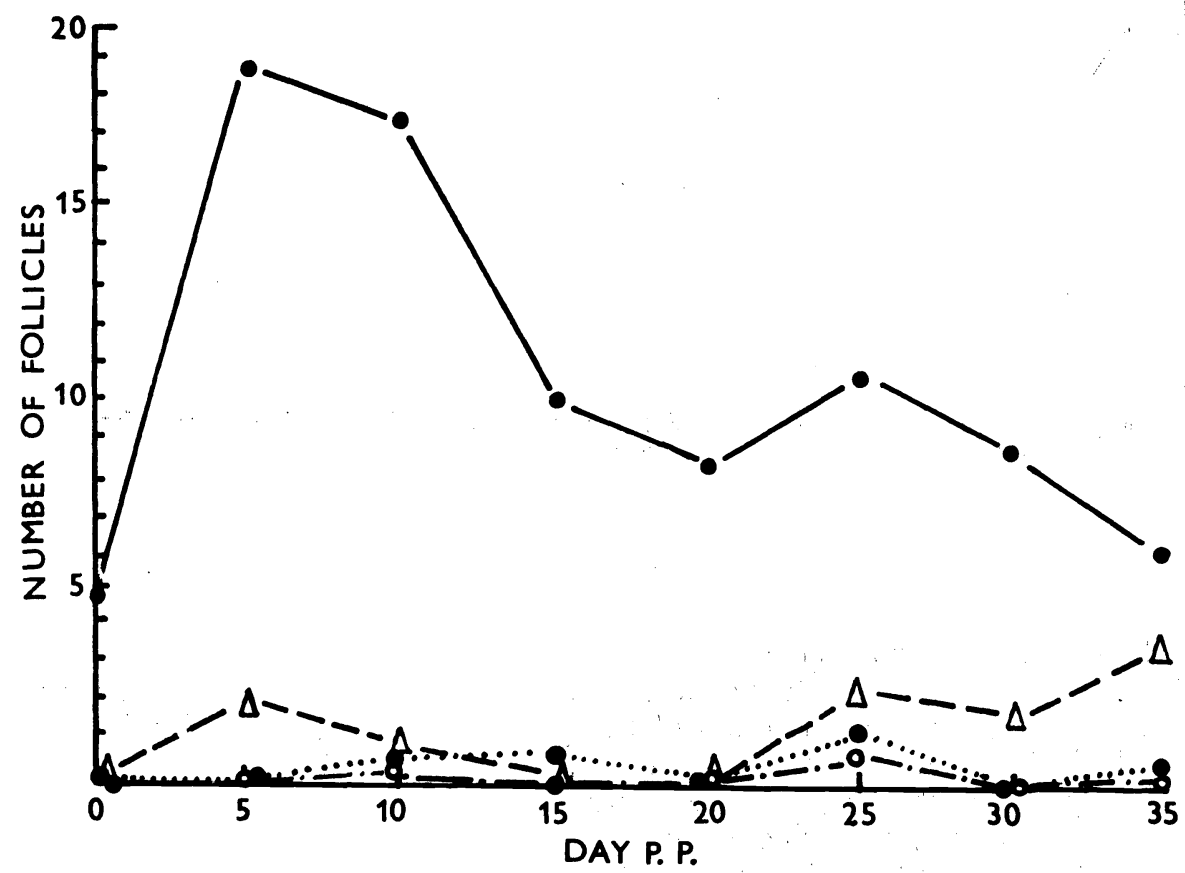

Fig. 2. Average numbers of the various ipsilateral ovarian follicles related to post partum interval in cows

15, we ascertained the cervix uteri above the cranial half of the pelvic floor, the corpus above its cranial extreme, the horns were identifiable and turned ventrolaterocaudally to various extent, partially or completely extending over the pelvis to the abdominal cavity, or extending deeper in the cranioventral direction. Fom day 20 after parturition, we did not find any substantial changes in the position of individual section of the uterus. The cervix uteri was palpated above the middle section of the pelvic floor, the corpus above its cranial section, with the horns twisted to a various degree in the ventrolaterocaudal direction and extending partially or completely over the pelvis into the abdominal cavity. Until day 35 post partum the previously pregnant uterine horns were usually longer, extending deeper into the abdominal cavity.

The width of individual parts of the uterus on the parturition day was measured at the cervix uteri and corpus, the previously pregnant horn and the nonpregnant horn, the results being $15-20 \mathrm{~cm}, 20-30 \mathrm{~cm}$ and $10-15 \mathrm{~cm}$ respectively. The width of the cervix uteri was gradually reduced to $6-10 \mathrm{~cm}$ in the experimental part of our study and to 8-12 $\mathrm{cm}$ in the field part of our study on day 5, $6-10 \mathrm{~cm}$ on day $10,5-8 \mathrm{~cm}$ on day 15 and $4-6 \mathrm{~cm}$ on day 20 . From that time on, the values remained unchanged. Very similar values were also found in the corpus uteri. The previously gravid uterine horn was $10-15 \mathrm{~cm}$ wide on day $5,6-8$ and $6-10 \mathrm{~cm}$ wide on day 10 in the experimental and field part of the study respectively, $4-6 \mathrm{~cm}$ on day $15,3-5$ and $4-6 \mathrm{~cm}$ on days $20-30$ in the experimental and field parts of the study respectively, and $3-5 \mathrm{~cm}$ from day 35 post partum. 


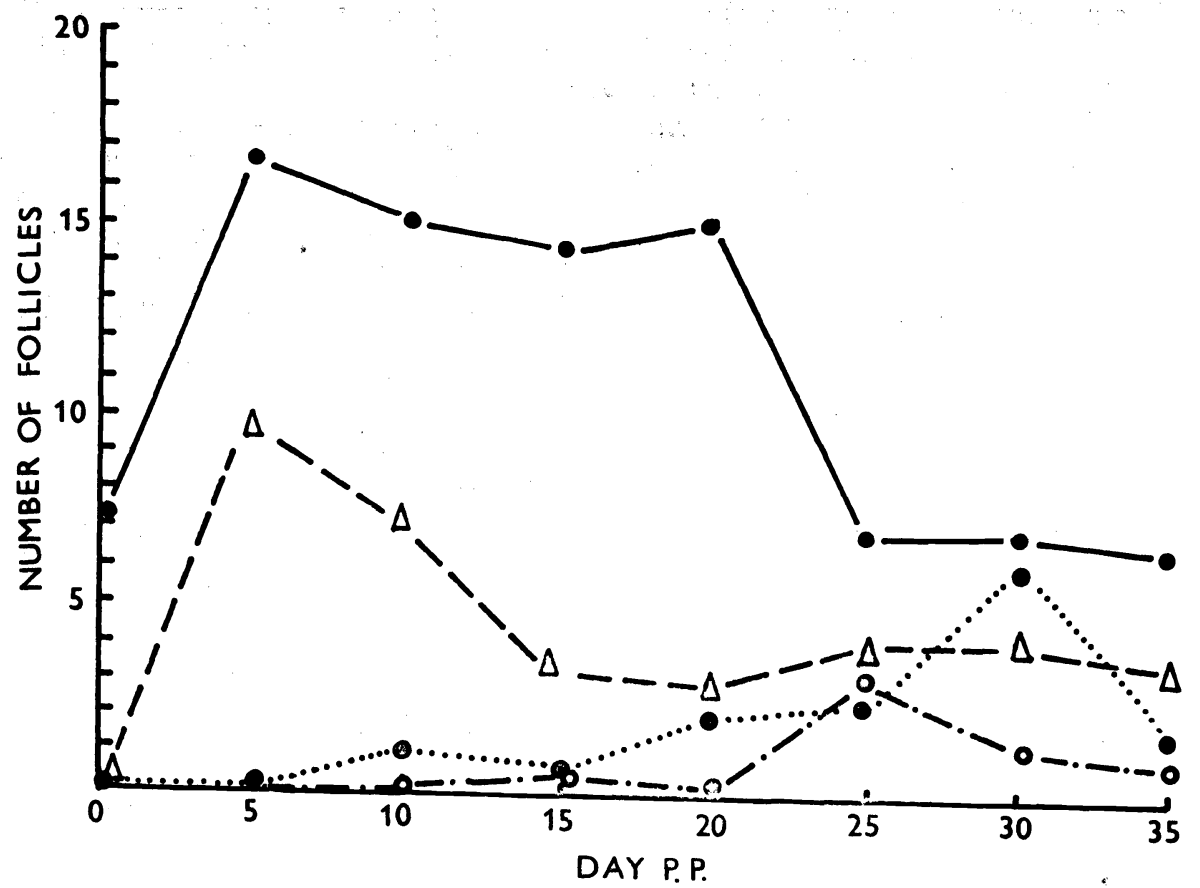

Fig. 3. Average numbers of the various contralateral ovarian follicles related to post partum interval in cows

Fig. 2, 3.
$\varnothing 1-3 \mathrm{~mm}$
$\varnothing 4-6 \mathrm{~mm}$
$\varnothing 7-10 \mathrm{~mm}$
$\varnothing 11 \leq \mathrm{mm}$
$\longrightarrow$
$\Delta-\cdots \Delta$
- …….......
$0 \longrightarrow 0$

In the previously nonpregnant horn, we measured $6-8 \mathrm{~cm}$ on day $5,4-6$ and $4-8 \mathrm{~cm}$ on day 10 in the experimental and field part of the study respectively, $3-5 \mathrm{~cm}$ on day 15 , and $2-4$ and $3-5 \mathrm{~cm}$ in the experimental and field part of the study respectively from day 20 . From day 35 , the values in the latter also dropped to $2-4 \mathrm{~cm}$. From day 35 post partum we did not find any marked asymmetry between uterine horns reflecting the lateral character of the previous pregnancy.

On the parturition day, the uterine wall was roughened, non-elastic, with marked longitudinal grooves. Caruncles and fluid content were more or less clearly palpable through the wall. From day 5, the uterine wall was gradually getting a softer and more elastic character with less marked longitudinal grooves. From day 10, the surface of the uterine wall was smooth or with small longitudinal grooves only, soft to tough elastic, slightly, medium or strongly tonified without and content or caruncles palpable in the uterine cavity.

Ovaries became gradually palpable from day 5 post partum. We were usually able to first palpate the ovary contralateral to the previously pregnant uterine horn, on rare occasions both ovaries deep cranioventrally in the abdominal cavity below the level of the pelvic floor. On day 15, both ovaries were easily accessible at the level of the pelvic floor in the abdominal cavity near the cranial end of the pelvic floor. From day 20, the situation was similar to that of the uterus and no 
further substantial changes in the position of the ovaries were ascertained. The ovaries were found in the pelvic or abdominal cavity near the cranial end of the pelvic floor at the level of the floor or above it.

The size of the ovaries was in the range of $2-4.5 \mathrm{~cm} \times 1-3.5 \mathrm{~cm} \times 1-3 \mathrm{~cm}$. In the case that both ovaries were palpable on day 5 post partum, the ovaries ipsilateral to the previously pregnant uterine horn were bigger than the contralateral ones. On day 10, the size of ovaries was the same, while on days 15 and 20 the contralateral ones were bigger. From day 25 post partum the size of the ovaries became the same again and from days 35-40, bigger ovaries were usually found on the right side. The regressing gravid corpora lutea were palpated on ipsilateral ovaries nutil day $10-20$ post partum. Besides, one or more follicles, about $0.5 \mathrm{~cm}$ in diameter, were irregularly detected, from day 15 also follicles measuring 1 to $1.5 \mathrm{~cm}$ in diameter. From day 25, we detected a gradually increasing incidence of corpora lutea on ipsilateral ovaries. On contralateral ovaries, we found one or more follicles about $0.5 \mathrm{~cm}$ in diameter on day 5 post partum, and follicles about $1 \mathrm{~cm}$ in diameter were often detected from day 10 . Besides varied follicular population, we found small atypical luteal structures or clearly detectable corpora lutea. From day 25, corpora lutea were frequently found in contralateral ovaries. From day 35, both ovaries usually presented a finding typical for a sexual cycle.

c) Macroscopic Examination of the Reproductive Tract of Slaughtered Cows in the Post-Partum Period

The mean values of the width of individual sections of the uterus got gradually smaller from parturition to day $15-20$ post partum, when they became practically constant (Table 1). The most marked shortening of individual sections of the uterus took place from the parturition to day 10-15 after parturition (Table 2). The mean weight of the uterus was decreasing markedly until day 10 post partum, less markedly until day 20, when it levelled off (Fig. 1). The mean size of the ovaries was in the range of $3-4.5 \mathrm{~cm} \times 2-3 \mathrm{~cm} \times 1-2.5 \mathrm{~cm}$. Until day 10 post partum, the size of ipsilateral ovaries was slightly bigger but from day 15, the size of ovaries became equal and from days 30 and 35 the size of the ovaries contralateral to the previously pregnant uterine horn was bigger. Besides the remains of old corpora lutea, we were able to demonstrate gradually regressing gravid corpora lutea up to day 25 post partum on ipsilateral ovaries. When evaluating various follicular populations, we grouped them according to the following four classes by diameter: $1-3 \mathrm{~mm}, 4-6 \mathrm{~mm}, 7-10 \mathrm{~mm}, 11 \mathrm{~mm}$ and more. The number of small follicles increased markedly on days 5-15 post partum and then dropped again. Follicles belonging to the Class 2 by size were found from day 5 post partum and their number on contralateral ovaries was markedly higher. The numbers got the same from day 15, although at a generally lower level. Class 3 follicles were found irregularly on ovaries frmo day 10 and Class 4 follicles with diameters of $11 \mathrm{~mm}$ and more from day 15 post partum. Class 3 and 4 follicles were found more frequently on contralateral ovaries (Fig. 2 and 3 ).

From day 10 post partum, the mean weight of contralateral ovaries gradually increased and from day 20, it was higher than that of ipsilateral ovaries (Fig. 4).

\section{d) Endocrinological Examination}

Mean serum progesterone concentrations decreased from $1.5 \pm 1.85$ and $0.8 \pm 0.56 \mathrm{ng} / \mathrm{ml}$ on the parturition day to $0.4 \pm 0.30$ and $0.5+0.38 \mathrm{ng} / \mathrm{ml}$ on day 5 post partum in the experimental and field part of our study respectively, remained on the same level until day 15 and then grew slightly to attain the maxi- 


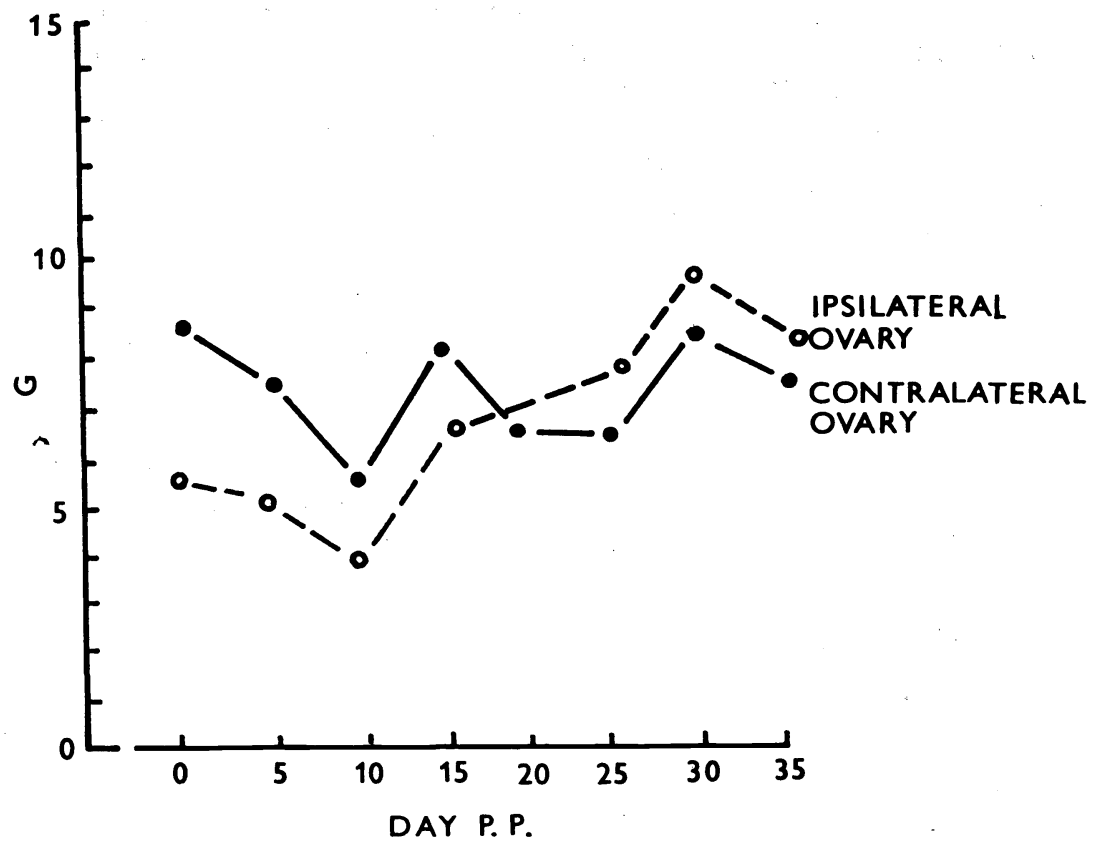

Fig. 4. Average mass of the bovine ovaries related to post partum interval

mum levels on days $30-40$ (3.1 \pm 5.08 and $3.7 \pm 2.67 \mathrm{ng} / \mathrm{ml}$ respectively). According to serum progesterone concentrations, we divided the cows into four groups, i.e. with no incretion activity of luteal structures of the ovaries $(0.00-0.05 \mathrm{ng} / \mathrm{ml}$ serum progesterone), with sporadic activity $(0.6-1.0 \mathrm{ng} / \mathrm{ml})$, slight activity $(1.1$ to $2.0 \mathrm{ng} / \mathrm{ml}$ ) and strong activity $(2.1 \mathrm{ng} / \mathrm{ml}$ and over). The largest number of cows with sporadic activity was found on days 20 and 25 post partum. Then there was an increase in the number of cows with a slight or strong activity of steroidogenesis of ovarial luteal structures.

\section{Discussion}

Our finding that distinct involutional changes on the uterus in cows are completed by day 20 after parturition differs slightly from conclusions reached by Gier and Marion (1968), Morrow et al. (1969) and Kudláč and Vlček (1970), who mention day 25 post partum. In agreement with the above authors, we were able to demonstrate that both uterine horns can be identified by palpation per rectum from days $10-15$ post partum. In agreement with Tennant et al. (1967), we found that from day 30 the width of the previously pregnant uterine horn was the same as the cervix uteri, and smaller from day 35 post partum. Our results also confirm conclusions of Arthur et al. (1989) that the width and length of the previously pregnant uterine horn in cows $(25-30 \mathrm{~cm}$ and $70-80 \mathrm{~cm}$ at the time of parturition respectively) are halved on days 5 and 15 respectively. Withing 30 and 35 days post partum, we regularly demonstrated 
an asymmetry of uterine horns, with the previously pregnant uterine horn on average $1 \mathrm{~cm}$ wider than the other uterine horn. These data are in agreement with the findings of Wagner and Hansel (1969). The maximum width of uterine horns on day 30 post partum for physiological involution in a similar breed of cows reported by Mor row (1981) was $4 \mathrm{~cm}$. In our study, a comparable result was obtained in a macroscopic examination during autopsy. In the clinical part, however, the maximum width that we found on that day was $5 \mathrm{~cm}$, and $4 \mathrm{~cm}$ width was not ascertained before day 40 post partum. The width of the cervix uteri immediately after parturition $(15-20 \mathrm{~cm})$ is similar to the value published by Arthur et al. (1989). In our study, however, its involution was much faster. Compared to the width of $9-10 \mathrm{~cm}$ on day 10 and $7-8 \mathrm{~cm}$ on day 30 , our values were $5-8 \mathrm{~cm}$ and $4-6 \mathrm{~cm}$, which corresponds to values ascertained by Studer and Morrow (1981). Our data on the closing of the orificium cervicis externum et internum (days $15-20$ and 30 , respectively) are in agreement with the findings of the above authors. Slightly faster uterine involution in the experimental part of our study was probably caused by the cattle breed used (also crossbreds with Black Pied Lowland breed) and the method of housing (continuous presence of calves with their dams and suckling).

Wagner and Hansel (1969) ascertained that on day 7 after parturition the mean mass of the ovaries ipsilateral and contralateral to the previously pregnant uterine horn was $7.07 \mathrm{~g}$ and $3.88 \mathrm{~g}$, respectively. We found similar values on days $5(7.5 \mathrm{~g}$ and $5.0 \mathrm{~g}$ ) and $10(5.5 \mathrm{~g}$ and $3.7 \mathrm{~g})$. According to Garcia (1982), the weight ratio between the ipsi- and contralateral ovaries changes on day 30, in our work the ratio changed already from day 20 post partum. Our macroscopic findings support the data published by Labhsetwar et al. (1964) and Schirar and Martinet (1982) which showed that the ovaries exhibit only a small number of follicles with diameter of up to $3 \mathrm{~mm}$ at parturition. Consistent with our results, Kesler et al. (1979), Garcia (1982) and Duby et al. (1985) demonstrated a marked increase in the number and growth of medium-size follicles from day 4, which attained the size of a pre-ovulation follicle on about day 15 post partum, with the constant number of small follicles of up to $3 \mathrm{~mm}$ in size (Spicer et al. 1986). In our study, a small decrease in the number of follicles with up to $3 \mathrm{~mm}$ in diameter from day 15 post partum was recorded. The small (about $1 \mathrm{~cm}$ in diameter) atypical luteal structures on the ovaries, which were sporadically demonstrated in our study from days 20 to 25 post partum, are considered by some authors as not fully functional corpora lutea appearing after the 1st post-partum ovulation (Lauderdale et al. 1968; Morrow 1971; Edgerton and Hafs 1973; Duby et al. 1985; Moss et al. 1985; Rutter and Randel 1985 ) or as luteinised unovulatory follicles (Schams et al. 1978; Garcia 1982). According to the above authors, these structures are responsible for the slight and short first post-partum increase in the concentration of progesterone in peripheral blood, stimulating probably the onset of a cyclical ovarian activity. In our study, the finding of these luteal structures on day $20-25$ post partum was accompanied by a marked increase in the number of cows with a sporadic activity of ovarian luteal structures and slightly increased serum progesterone concentrations $(0.6-1.0 \mathrm{ng} / \mathrm{ml})$. The occurrence of well-developed corpora lutea from day 30 post partum confirms the finding of Kudláč and Vlček (1970) that the majority of the Bohemian Pied cows first ovulates between day 21 and 30 after parturition. In agreement with the results by Morrow et al. (1968), Schirar an Martinet (1982), Spicer et al. (1986) and Pierson and Ginther 
(1987), we demonstrated a one-sided inhibition of folliculogenesis and the genesis of luteal structures on the side of the previously pregnant uterine horn and ovaries with the remains of the gravid corpora lutea. The mechanism of this effect has not been quite elucidated yet. The above authors have demonstrated that on this side the follicles are generally smaller, larger follicles are generally smaller, larger follicles are less numerous, and the concentrations of oestradiol 17-beta in the follicular fluid are lower, the level of atretic changes is higher and the ovulation and corpora lutea appear later. Even though we found the same number of pregnancies on both the right and the left sides in the experimental part of our work, in the field part the percentage ratio was $59: 41 \%$, respectively. This finding is in agreement with a concept of higher activity and more frequent pregnancies in cows on the right side generally accepted by the above authors who more frequently demonstrate an early post-partum inhibition of folliculogenesis on the right side.

To summarize, we can state that marked and clinically well-detectable involution changes on the uterus in pluriparous cows, crossbreds (Bohemian Pied $\times$ $\times$ Holstein-Friesian cattle), take place by day 20 post partum. The maximum width of uterine horns on days 15,30 and 40 is $6 \mathrm{~cm}, 5 \mathrm{~cm}$ and $4 \mathrm{~cm}$, respectively. Higher values indicate a delayed course of uterine involution. The orificium cervicis internum et externum close on day 15 and 30 post partum, respectively. From day 5 to day 15 post partum, the number of medium-size $(3-10 \mathrm{~mm})$ follicles on the ovaries grows gradually. The growth is more marked on the contralateral side to the previously pregnant uterine horn, which often attain their largest size (11 mm and more) on days $15-20$ post partum. From day 20, it is possbile to demonstrate atypical luteal structures or well-developed corpora lutea on the ovaries on rare occasions.

The incidence of corpora lutea increased dramatically from day 30 post partum. Luteal structures were generally more frequently demonstrated on contralateral ovaries, which indicates that the ovarian function post partum is more frequently renewed on the ovary contralateral to the previously pregnant uterine horn. While the first post-partum ovulation also took place more frequently on the contralateral side, it cannot, however, be assumed that this is a constant phenomenon.

\section{Morfologie pohlavního ústrojí a hladiny sérového progesteronu u krav $v$ průběhu 45 dnư po porodu}

V provoznich podminkách chovu skotu (český strakatý $\times$ holštýnsko-fríský) $v$ pětidenních intervalech od porodu do 45 . dne po porodu jsme prováděli klinická vyšetřeni, odběry krve $\mathrm{z} v$. jugularis pro stanovení sérového progesteronu a u části krav do 35. dne pp. makroskopická vyšetření pohlavních orgánů post mortem. Klinicky jsme prokázali uzavření vnitřní děložní branky 15.-20. den a vnější 30. den pp. Do 20. dne pp. se děloha postupně retrahovala do pánve a od 10. dne jeji stěna nabyla vlastností negravidní dělohy. Vaječníky palpovatelné od 5.-10. dne pp. většinou vykazovaly od 35. dne typický nález pro probíhající pohlavni cyklus. Makroskopicky jsme zjistili výrazné zmenšováni dělohy do 10. dne, méně výrazné do 20. -25 . dne pp. Její hmotnost se snížila z $10 \pm 1,6 \mathrm{~kg} \mathrm{v}$ den porodu na $2,3 \pm 0,9 \mathrm{~kg} \mathrm{10}$. den a $0,9 \pm 0,020$. den $\mathrm{pp}$. Průměrná hmotnost kontralaterálních vaječnikủ $k$ dřive březímu děložnímu rohu se od 10 , dne $\mathrm{pp}$. $(3,7 \pm$ 
$\pm 0,91 \mathrm{~g})$ postupně zvyšovala na $6,8 \pm 3,06 \mathrm{~g} 20$. den, kdy převýšila hodnoty ipsilaterálních vaječníkủ $(6,3 \pm 2,92 \mathrm{~g})$. Počet ovariálních folikulů $\mathrm{s}$ rozměry $1-3 \mathrm{~mm}$ se od 5 . do 15 . dne pp. výrazně zvýšil. Folikuly nad $3 \mathrm{~mm}$ zjištované od 5. dne pp. kontralaterální vaječníky vykazovaly ve větším množství. Nepatrně zvýšenou koncentraci sérového progesteronu $(0,6-1,0 \mathrm{ng} / \mathrm{ml})$ jsme nejčastěji zjištovali 20. a 25 . den pp., poté se zvyšoval výskyt krav s hladinami 1,1 a více $\mathrm{ng} / \mathrm{ml}$.

\section{Морфология полового аппарата и үровень сывороточного прогестерона коров в течение 45 сүток после отела}

В производственных условиях разведения крупного рогатого скота (чешская пестрая и гольштейнско-гризская породы) в пятисуточных интервалах, начиная отелом вплоть до 45 суток после отела проводили клинические исследования, отбор крови из яремной вены с целью орределения сывороточного прогестерона и у части коров до 35 суток после отела проводили макроскопические исследования половых органов пост мортем. Нами было клинически установлено закрытие внутренней маточной стенки на $15-20$ сутки и внешней на 30 сутки после отела. До 20 суток после отела матка постепенно втягивалась в таз и с 10 сүток ее стенка приобрела свойство небеременной матки. Пальпируемость ячников начиная с 5-10 сүток после отела большей частью с 35 суток они свидетельствовали о протекании полового цикла. Макроскопически нами было установлено выразительное уменьшение влагалища до 10 суток, менее выразительное до 20-25 суток после отела. Его масса уменьшилась с $10 \pm 1,6 \mathrm{kr}$ в день отела до 2,3 $\pm 0,9 \mathrm{kr}$ на 10 сутки и 0,9 $\pm 0,0$ кг на 20 сутки после отела. Средняя масса контралатеральных яичников по отношению к ранее переменному маточному углу с 10 суток после отела $(3,7 \pm 0,91 \mathrm{kr})$ постепенно увеличивалась до 6,8 3,06 г на 20 сутки, когда превышала величину ипсилатераляных яичников $(6,3 \pm 2,92$ г). Число овариальных фолликулов размером 1-3 мм с 5 по 15 сүтки после отела выразительно увеличилось. Фолликулы более 3 мм, выявляемые начиная 5 сүтками после отела, появлялись в большем количестве в контралатеральных яичниках. Незначительно повышенную концентрацию сывороточного прогестерона (0,6-1,0 нг/мл) чаще всего установили на 20-25 сутки после отела, после этого увеличивалась численность коров с уровнем 1,1 и больше нг/мл.

\section{References}

ARTHUR, G. H.-NOAKES, D. E.-PEARSON, H.: Veterinary reproduction and obstetrics. (6. edition). Baillière-Tindall, London, 1989: $641 \mathrm{p}$.

BRITT, J. H.-MORROW, D. A. - KITTOK, R. J.-SEGUIN, B. E: Uterine involution, ovarian activity, fertility after melengestrol acetate and estradiol in early postpartum cows. J. Dairy Sci., 57, 1974: 89-92

DUBY, R. T. - BROWNING, T.-CAREY, D.-BLACK, D. L.: Progesterone synthesis and histology of postpartum bovine corpora lutea. Theriogenology, 23, 1985: 619-630

EDGERTON, L. A-HAFS, H. D.: Serum luteinizing hormone, prolactin, glucocorticoid and progestin in dairy cows from calving to gestation. J. Dairy Sci., 56, 1973: $451-458$ 
GARCIA, M.: Reproductive functions during the post partum period in the cow. Nord. Vet. Med., 34, 1982: 264-275

GARCIA, M.-LARSSON, K.: Clinical findings in post partum dairy cows. Nord. Vet. Med., 34, 1982: 255-263

GIER, H. T.-MARION, G. B.: Uterus of the cow after parturition: Involutional changes. Am. Vet. Res., 29, 1968: 83-96

HAFEZ, E.S. E.: Reproduction in farm animals. Lea \& Febiger, Philadelphia, 1987: 633 p.

KESLER, D. J.-GARVERICK, H. A.-BIERSCHWAL, C. J.-ELMORE, R. G.-YONGQUIST, R. S. Reproductive hormones associated with normal and abnormal changes in ovarian follicles in postpartum dairy cows. J. Dairy Sci., 62, 1979: 1290-1296

KING, G. J.-HURNIK, J. F.-ROBERTSON, H. A.: Ovarian function and estrus in dairy cows during early lactation. J. Anim. Sci., 42, 1976: 688-692

KUDLÁČ, E.: Výskyt, příciny a některé metody therapie anestru u skotu. Habilitation thesis, University of Veterinary Science Brno, 1964, 260 p.

KUDLÁČ, E.-ELEČKO, J.: Veterinární porodnictví a gynekologie. SZN Praha, 1987, 572 p.

KUDLÁC, E.-VLČEK, Z.: Klinické změny na pohlavním ústrojí a obsah baktérií v děloze krav po normálním porodu. Vet. Med. (Praha), 15, 1970: 11-19

LABHSETWAR, A. P. - COLLINS, W. E. - TYLER, W. J. - CASIDA, L. E.: Some pituitary ovarian relationship in the periparturient cow. J. Reprod. Fert. 8, 1964: 85-90

LAUDERDALE, J. W.-GRAVES, W. E.-HAUSER, E. R.-CASIDA, L. E.: Relation of post partum interval to corpus luteum development, pituitary prolactin activity, and uterine involution in beef. Wisc. Agric. Exp. St. Res. Bull., 270, 1968: 42-48

MARION, G. B.-GIER, H. T.: Factors affecting bovine activity after parturition. J. Anim. Sci., 27, 1968: $1621-1626$

MOLLER, K.: Uterine involution and ovarian activity after calving. N. Z. Vet. J., 18, 1970: $140-145$

MORROW, D. A.: Effects of periparturient disease on postpartum reproduction in dairy cattle. J. Anim. Sci., 32, 1971: 17-21

MORROW, D. A. : Examination schedule for a dairy reproductive program. Irish. Vet. J., 35, 1981 : $86-89$

MORROW, D. A.-ROBERTS, S. J.-MC ENTEE, K.: Latent effects of pregnancy on postpartum ovarian activity in dairy cattle. J. Anim. Sci., 27, 1968: 1408-1411

MORROW, D. A.-ROBERTS, S. J.-MC ENTEE, K.: Postpartum ovarian activity and involution of the uterus and cervix in dairy cattle. Cornell. Vet., 59, 1969: 173-210

MOOS, G. E.-PARFET, J. R.-MARVIN, C. A.-ALLRICH, R. D.-DIEKMAN, M. A.: Pituitary concentrations of gonadotropins and"receptors for $\mathrm{GnRh}$ in suckled beef cows at various intervals after calving. J. Anim. Sci., 60, 1985: 285-293

PIERSON, R. A.-GINTHER, O. J.: Follicular populations during the estrous cycle in heifers. II. Influence od right and left sides and intraovarian effect of corpus luteum. Anim. Reprod. Sci., 14, 1987: 177-186

PfCHOVA, D.: Kontrola estru a fertilní inseminace pomocí RIA stanovení progesteronu v mléce. Project report DVÚ 329-2-01 VUŽV Uhříněves 1977, 35 p.

RASBECH, N. O.: Den normale involution uteri hos koen. Nord. Vet. Med. 2, 1950: 655-687

RUTTER, L. M. - RANDEL, R. D.: Luteal competency during the resumption of ovarian cyclicity in postpartum Brahman cows. Theriogenology, 5, 1985, 713-725

SCHAMS, D.-SCHALLENBERGER, E.-MENZER, CH.-STANGL, J.-ZOOTMEIER, K. - HOFFMANN, B. - KARG, H.: Profiles of LH, FSH, and progesterone in postpartum dairy cows and their relationship to the commencement of cyclic functions. Theriogenology, 10, 1978: $453-468$

SCHIRAR, A. - MARTINET, J.: Postpartum ovarian activity and its interaction with the uterus in resuming cyclic activity post partum. In.: Factors influencing fertility in the postpartum cow. The Hagu (Boston) London, Martinus Nijhoff Publishers, 1982: 67-94

SCHULZ, L. CH.-GRUNERT, E.: Physiologie und Pathologie der puerperalen Involution des Rinder uterus. Dtsch. tierärztl. Wschr., 66, 1959: 29-37

SHIPILOV, V. S.: Funkcionalnoe sostojanie jaichnikov u korov posle roda. Trudy MTA selskochozjajstvenych nauk, Moskva, 4, 1958: $150 \mathrm{p}$.

SPICER, L. J.-LEUNG, K.-CONVEY, E. M.-GUNTHER, J.-SHORT, R. E.-TUCKER, H. A.: Anovulation in postpartum suckled beef cows. I. Association among size and numbers of ovarian follicles, uterine involution, and hormones in serum and follicular fluaid. J. Anim. Sci., 62, 1986: 734-741

STUDENOV, A. P. - SHIPILOV, V. S. - SUBBOTINA, L. G. - PREOBRAZHENSKIJ, O. N.: Veterinarnoe akusherstvo i ginekologia. Agropromizdat Moskva, 1986: 479 p. 
STUDER, E.-MORROW, D. A.: Examination and interpretation of findings of the postpartum reproductive tract in dairy cattle. Irish Vet. J., 35, 1981: 171-177

TENNANT, B.: Uterine involution and ovarian function in the postpartum cow. A retrospective analysis of 2338 genital organs examinations Cornell Vet., 57, 1967:543-557

THATCHER, W. W. - WILCOX, C. J.: Post partum estrus as an indicator of reproductive status in the dairy cow. J. Dairy Sci. 56, 1973: 608-610

WAGNER, W. C. - HANSEL, W.: Reproductive physiology of the postpartum cow. Clinical and histological findings. J. Reprod. Fert., 18, 1969: 493-500

WHITMORE, H. L. - TYLER, W. J.-CASIDA, L. E.: Effect of early postpartum breeding in cattle. J. Anim. Sci., 38, 1974: 339-346 